\title{
Taxonomy of the Hister criticus group, with description of a new species (Coleoptera: Histeridae)
}

\author{
MICHAEL S. CATERINO \\ Department of Invertebrate Zoology, Santa Barbara Museum of Natural History, 2559 Puesta del Sol Rd., \\ Santa Barbara, CA 93105 USA. Email: mcaterino@sbnature2.org
}

\begin{abstract}
The Hister criticus group is created and defined to include 5 species: Hister criticus Marseul, $H$. laevimargo Lewis (= H. planimargo Lewis, New Synonomy), H. latimargo Schmidt, H. foveipygus Wenzel and Dybas, and H. guanacaste $\mathrm{n}$. sp. These species occur in the Neotropical region, ranging from Panama north to extreme southern Arizona (USA). Hister latimargo appears to be an obligate associate of leafcutter ants (Atta spp.), while H. criticus has been collected in woodrat (Neotoma spp.) nests. Ecological associations for the other species are unknown. The existing species are redescribed, diagnostic characters (protibiae, pygidia, male and female genitalia) are illustrated, and habitus photographs of all species are presented. Lectotypes are designated for $H$. criticus, H. laevimargo, and $H$. planimargo.
\end{abstract}

Key words: Coleoptera, Histeridae, new species, taxonomy, Hister criticus group

\section{Introduction}

The New World fauna of Histerini comprises approximately 120 known species, distributed among 6 genera (Atholus Thomson, Epiglyptus Lewis, Hister Linnaeus [including subg. Spilodiscus Lewis], Merohister Reitter, Margarinotus Marseul, and Psiloscelis Marseul). Of the 78 of these included in Hister, 61 have so far been treated in a recent series of papers (Caterino 1998, 1999a, 1999b, 2002; Caterino \& Arriagada, 2003; Caterino \& Kovarik, 2001). The present paper treats a small group of primarily neotropical Hister species, which is informally designated the Hister criticus group. Four of the five species included here have been previously described. However, no previous authors have recognized a close relationship among them. This is due to relatively varied external morphology in the group, potentially attributable in part to inquilinous habits. Hister criticus Marseul itself ranges into southern Arizona, where it has been collected in woodrat 
(Rodentia: Muridae: Neotoma spp.) nests. The remaining four species occur from Mexico southward to at least Panama. Nearly all recent specimens of H. latimargo Schmidt have been collected in refuse piles of Atta mexicana (Smith). Little ecological data are available for the remaining three species in the group (H. foveipygus Wenzel \& Dybas, H. laevimargo Lewis, and $H$. guanacaste n. sp.), though the type of the first of these was collected in 'leaf mold' (Wenzel \& Dybas, 1941).

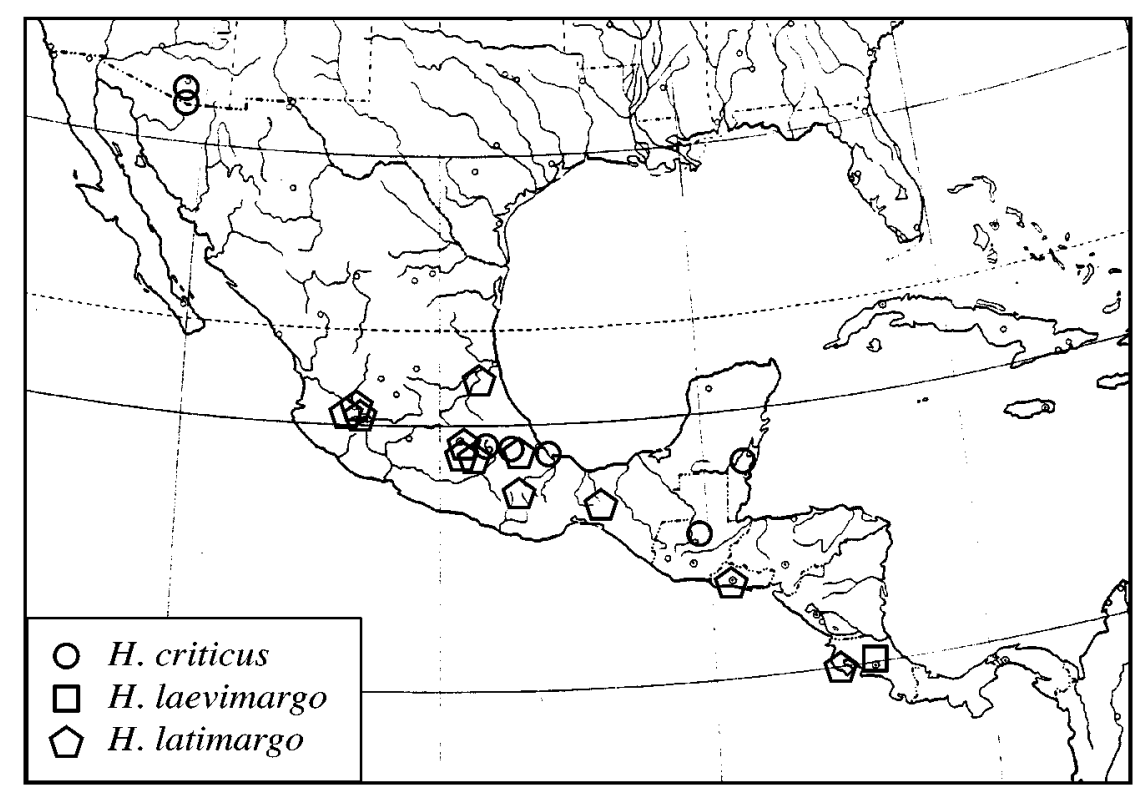

FIGURE 1. Map of specimen records for Hister criticus, H. laevimargo, and H. latimargo.

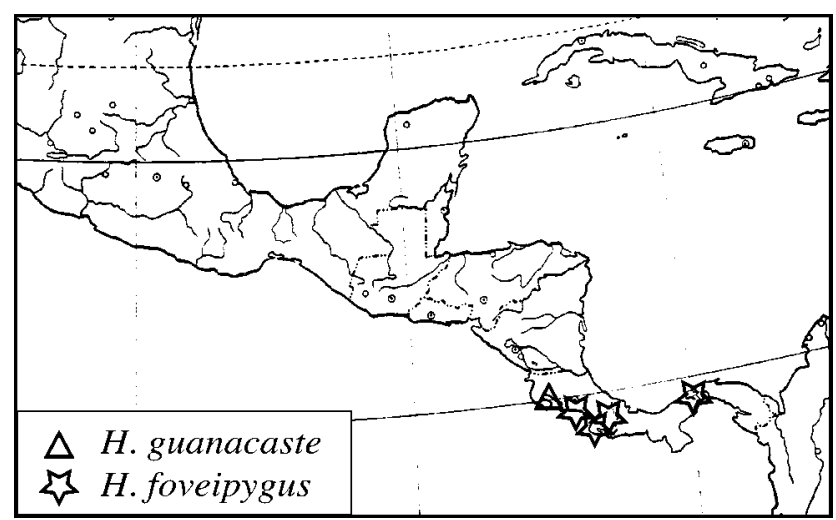

FIGURE 2. Map of specimen records for Hister guanacaste and $H$. foveipygus. 
There is no single character by which this group may consistently be distinguished from all other New World Hister. They are not keyed out as a group in either of the previous two papers with keys to New World Histerini (Caterino, 1999a, 1999b; in the latter keying out in the second halves of couplets 8 and 11). But through a combination of nearly constant characters, rare or absent in other groups, it is possible to separate these species from other New World Hister. These characters include (listed from most to least distinctive):

Pronotum unistriate, with the single lateral stria continuous with the anterior marginal stria behind the anterior pronotal emargination (Figs. 3, 7). While a few other New World Hister have just a single lateral stria (most have two), it usually ends freely in front (e.g. in H. sallei Marseul, and H. matador Caterino). Hister litus Marseul, H. californicus Marseul and $\mathrm{H}$. gringo Caterino share this configuration of pronotal striae with the criticus group. However, these are easily separated by the absent, or at least strongly reduced sutural elytral stria. In case of doubt the aedeagus of members of the litus group, with its elongate basal piece, is highly distinctive (see Caterino, 1999a for details and illustrations).

Protibia tridentate, with apical tooth bispinose and submarginal carina complete. This character is essentially invariant in the group (Fig. 5), while varying widely in other New World Hister. It is only difficult to apply to worn specimens (a surprisingly common condition in $H$. foveipygus Wenzel \& Dybas and $H$. guanacaste n. sp.). A fourth protibial tooth is seen in rare individuals, but usually only on one leg. The only other conceivably sympatric Hister to share this protibial configuration would be H. depurator Say (in the US southwest), which always has two lateral pronotal striae. Many members of the Hister servus group have the tibiae similarly dentate. But in these the submarginal carina is only present basally, meeting the lateral margin at one of the basal marginal teeth.

Propygidium and pygidium, as well as apical margin of each elytron, with conspicuous transverse microsculpture. This microsculpture may be largely obscured by coarse punctures on the propygidium and pygidium, but is even in these cases visible around the edges of the punctate areas. This distinctive microsculpture is also seen in a few other sympatric Hister spp.

Subhumeral elytral striae absent. The absence of these striae, while invariant in this group, is also observed in several other neotropical Hister in various groups.

Postmetacoxal stria doubled along inner margin of metacoxa. This character is apparently unique among neotropical Hister, though it is somewhat variable in H. foveipygus, with some individuals having only a single postcoxal stria, or only vague fragments of a second.

Supraorbital stria absent. While this is actually true of most other New World Hister, it is a useful feature by which to separate the group from the otherwise rather similar species $H$. servus Erichson and $H$. nodatus Lewis, both of which have the frontal stria continuous with a complete supraorbital. 

median acute process (Fig. 6D). The form of the aedeagus is strongly conserved in this group, with only minor variation in tegmenal shape evident. Superficially this type of aedeagus appears very similar to that seen in many members of the H. servus group. However, as far as I have been able to tell, the similar-looking apical armature of the median lobe in the criticus group is unarticulated, while in the $H$. servus group each arm of this structure rotates outward into tegmenal grooves upon extrusion of the median lobe.

\section{Repositories}

BMNH - The Natural History Museum, London

CASC - California Academy of Sciences Collection, San Francisco

CMNC - Canadian Museum of Nature, Ottawa

CZUG - Colección Entomologica, Universidad de Guadalajara

FMNH - The Field Museum, Chicago

INBI - Instituto Nacional de Biodiversidad, San José, Costa Rica

JSHC — James S. Hunter Collection, Arizona

MNHN — Muséum National d'Histoire Naturelle, Paris

MSCC - Michael S. Caterino Collection, Santa Barbara, California

PWKC - Peter W. Kovarik Collection, Columbus, Ohio

SEMC - Snow Entomological Collection, University of Kansas, Lawrence

UCRC - University of California, Riverside

USNM - National Museum of Natural History, Washington

ZMHB — Zoological Museum of Humboldt University, Berlin

\section{Species treatments}

\section{Hister criticus Marseul (Figs. 1, 3A, 4A, 5A, 6A)}

Hister criticus Marseul, 1861: 551; lectotype, probably male, hereby designated: "Mexique, Salle", MNHN; examined by the author; paralectotype male, hereby designated, same data and repository as type; two BMNH specimens labelled "Mexico, Salle coll."/ "Cordova" may also be syntypes, but this cannot be confirmed, and they are not formally recognized.

Diagnosis: Within this species group, Hister criticus is most easily recognized by the relatively sparse punctation of the propygidium and pygidium. Punctures of the propygidium are moderate in size and separated by nearly their widths throughout, while those of the pygidium are smaller and more widely spaced. On both the intervening integument is smooth and shining. In $H$. laevimargo, $H$. latimargo and $H$. foveipygus this punctation is much denser (Figs. 4B, C, E), and in H. latimargo, the intervening surface is densely alutaceous, while in $H$. guanacaste, the pygidia are impunctate (Figs. 4D). 
Description: Average length (from anterior pronotal margin to apex of elytral suture): $3.3 \mathrm{~mm}$ (range 3.1-3.6); Avg. width (at widest point): $3.2 \mathrm{~mm}$ (range 3.0-3.4); body black and shining, elongate oval, its outline not interrupted at the pronotal/elytral junction (Fig. $3 \mathrm{~A}$ ); frons broad, minutely punctate; frontal stria bisinuate; labrum twice as wide as long; apically truncate; mandibles flat above, notched at anterobasal corner; right mandible with small tooth at base below incisor edge; stipes with 4-6 setae; mentum convex, setose, emarginate at apex; penultimate labial palpomere with a crown of apical setae; apical labial palpomere with short scattered setae.

Pronotum widest at base, sides weakly converging anteriorly, inwardly curved at apex; marginal pronotal stria present from posterior corner to behind eye; outer lateral stria absent; inner lateral stria complete, continuous across anterior pronotal emargination, faintly crenulate; hypomeron bare; prosternal keel bistriate, striae divergent basally, parallel to slightly divergent at anterior apex; prosternal lobe rounded to nearly triangular; protibia tridentate, the apical tooth with two spines, deeply emarginate between marginal teeth, submarginal carina complete, bearing 2-3 small spinules along its length (Fig. 5A).

Elytra (Fig. 3A) lacking subhumeral striae; dorsal striae 1 and 2 complete, 3 complete or briefly interrupted at middle, 4th visible as short basal and apical fragments, 5th absent, sutural stria in apical two-thirds or less, nearly absent from some individuals. Mesosternum emarginate anteriorly, with complete marginal stria joining postmesocoxal stria at sides; mesometasternal stria broadly interrupted at middle, nearly absent between mesocoxae, laterally extending to middle of metepisternum; meso- and metasternal disks smooth at middle, shallowly punctate at sides; 1 st abdominal ventrite with two oblique striae along inner edge of each metacoxa; mesotibia weakly arcuate, metatibia nearly straight, both with two rows of marginal spines.

Propygidium faintly depressed on either side, with moderately large, shallow punctures, mostly separated by at least their diameters, punctures smaller and sparser at middle; pygidial punctures smaller, more evenly distributed, separated by about their diameters (Fig. 4A).

Male (Fig. 6A): aedeagus with tegmen only slightly expanded apically compared to others in this group.

Female: Only a single female has been seen, the reproductive tract of which did not clear well. Ovipositor shape and coxite/valvifer relative lengths as for $H$. guanacaste below.

Records (Fig. 1): MEXICO: Veracruz (BMNH); Veracruz, $10 \mathrm{mi} \mathrm{W.} \mathrm{Alvarado,} \mathrm{beach}$ debris - July (FMNH); Puebla, Cholula (FMNH); Cordova (FMNH); GUATEMALA, Cubilguitz, Vera Paz (BMNH); USA: AZ, Pima Co., Green Valley - April, Neotoma nest, (JSHC); AZ, Patagonia - July (CASC); BELIZE: Orange Walk Distr., Rio Bravo Conserv. Area, La Milpa Field Sta., FIT - May (PWKC).

Remarks: The two specimens from southern Arizona differ consistently from the other specimens in the short broadly rounded prosternal lobe, and in the near absence of the 

both in Neotoma (woodrat) nests, and under beach debris.

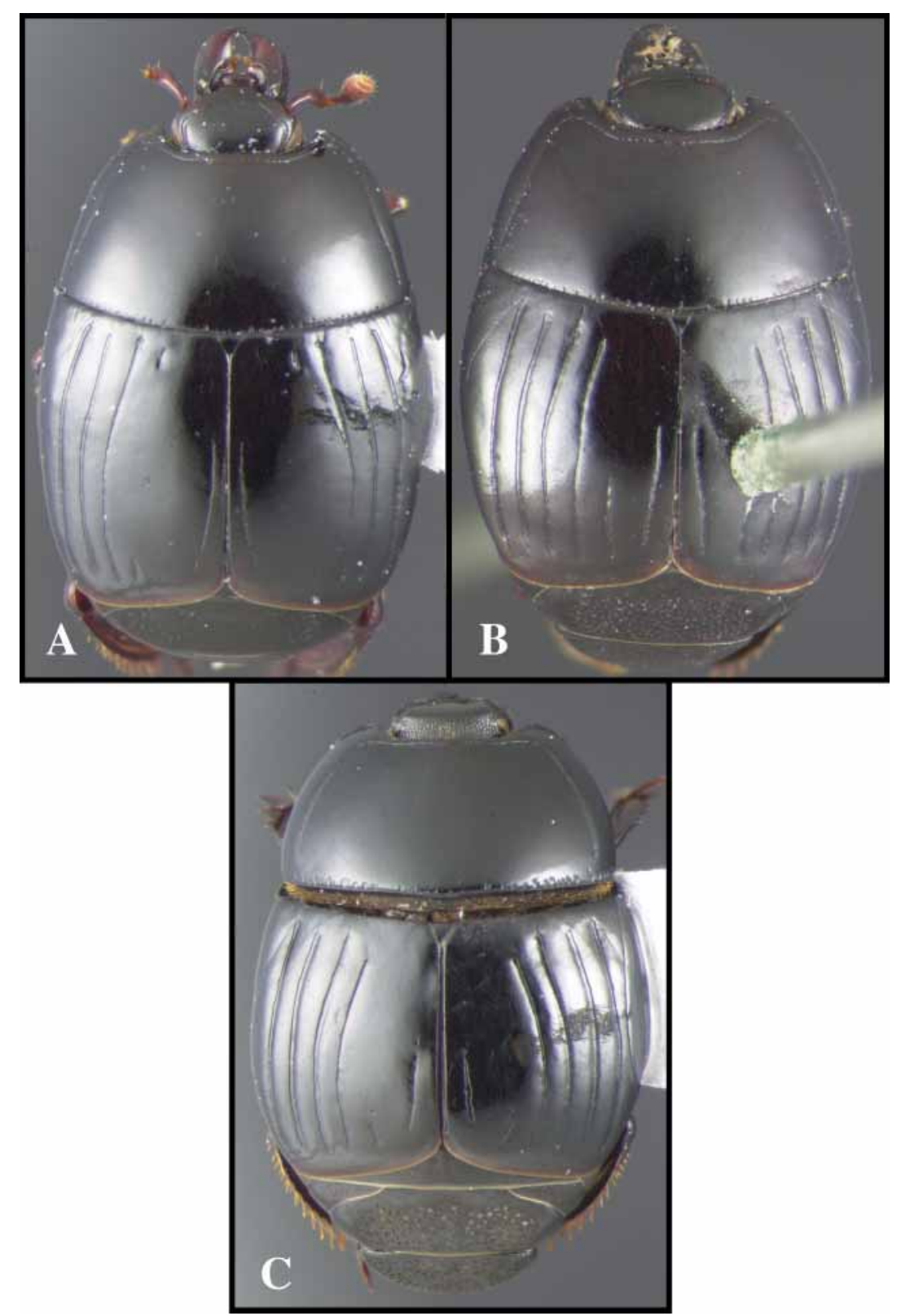

FIGURE 3. Dorsal habitus photographs of Hister spp. A. Hister criticus; B. H. laevimargo; C. H. latimargo. 


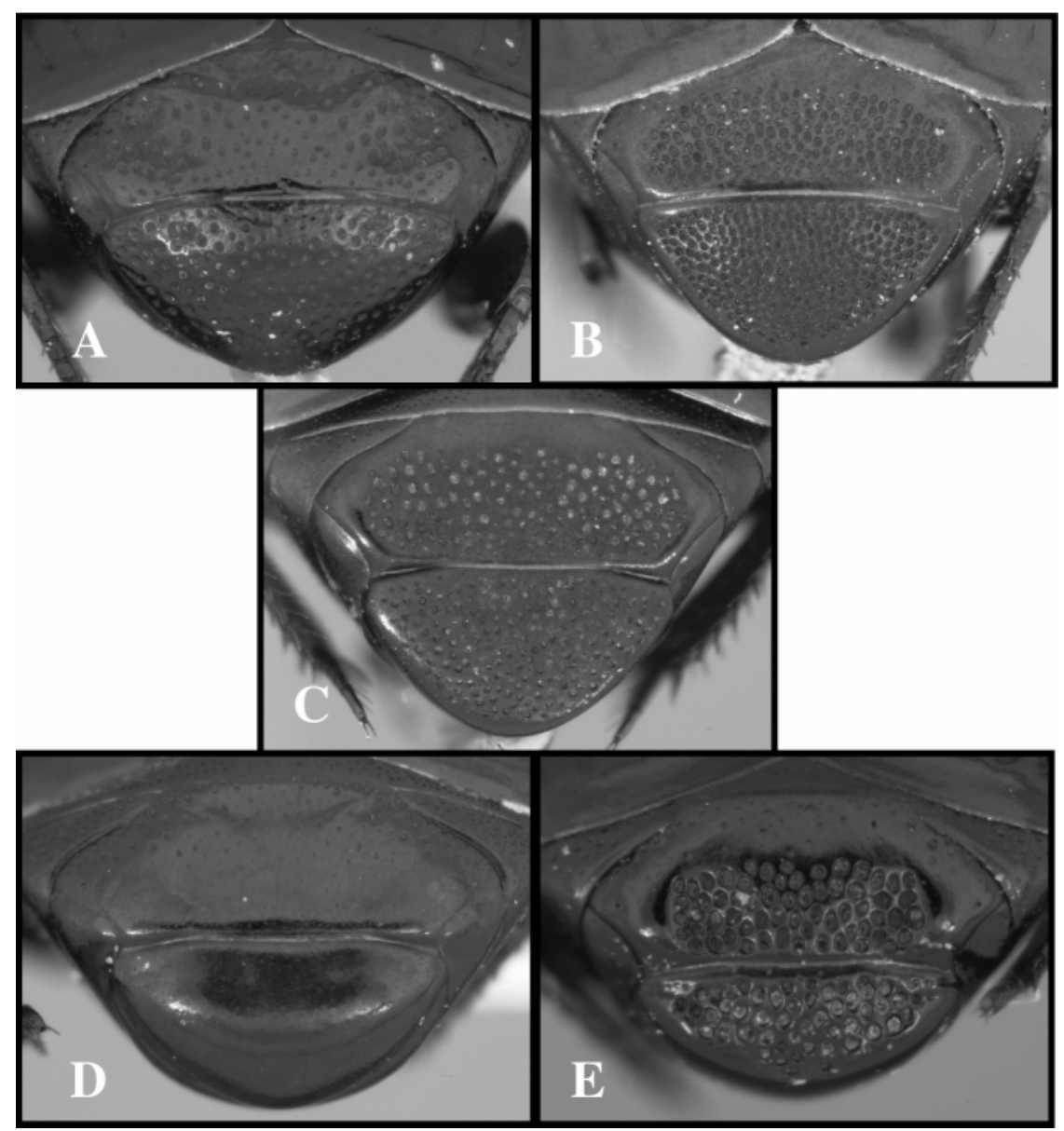

FIGURE 4. Photographs of propygidium and pygidium of Hister spp. A. Hister criticus; B. H. laevimargo; C. H. latimargo; D. H. guanacaste; E. H. foveipygus.

Hister laevimargo Lewis (Figs. 1, 3B, 4B)

Hister laevimargo Lewis, 1900: 246; lectotype female, hereby designated: "Costa Rica, P. Biolley"/ "G.Lewis Coll., B.M.1926-369."/ "Hister laevimargo Lewis Co-type"/ "Barba. Esmeralda, V.90, Troncs.", BMNH; examined by the author.

Hister planimargo Lewis, 1900: 247; lectotype, hereby designated: "Costa Rica, (Donckier)."/ "G.Lewis Coll., B.M.1926-369."/ "Hister planimargo Lewis Type", MNHN; examined by the author; Syn. nov.

Diagnosis: This species shares with $H$. criticus the relatively narrow lateral pronotal marginal bead (between the single lateral stria and the margin), and the presence of prosternal 
striae. However, elytral stria 4, interrupted or absent in $\mathrm{H}$. criticus, is complete in $\mathrm{H}$. laevimargo. The propygidial and pygidial punctation also differs substantially, with $\mathrm{H}$. laevimargo having relatively small, and very densely set punctures, most separated by one-third their diameters or less (Fig. 4B).

Description: Average length: $3.5 \mathrm{~mm}$ (range 3.2-3.8); Avg. width: $3.3 \mathrm{~mm}$ (range 3.03.6). This species is extremely similar to $H$. criticus, externally differing only in those characters given in the diagnosis. The aedeagus has not been examined because the species is only known from types in marginal condition.

Records (Fig. 1): This species is known only from the types. The type locality, Barba Esmeralda, apparently refers to a site on the slope of Volcán Barva in Heredia, about 20 km north of San José, Costa Rica.

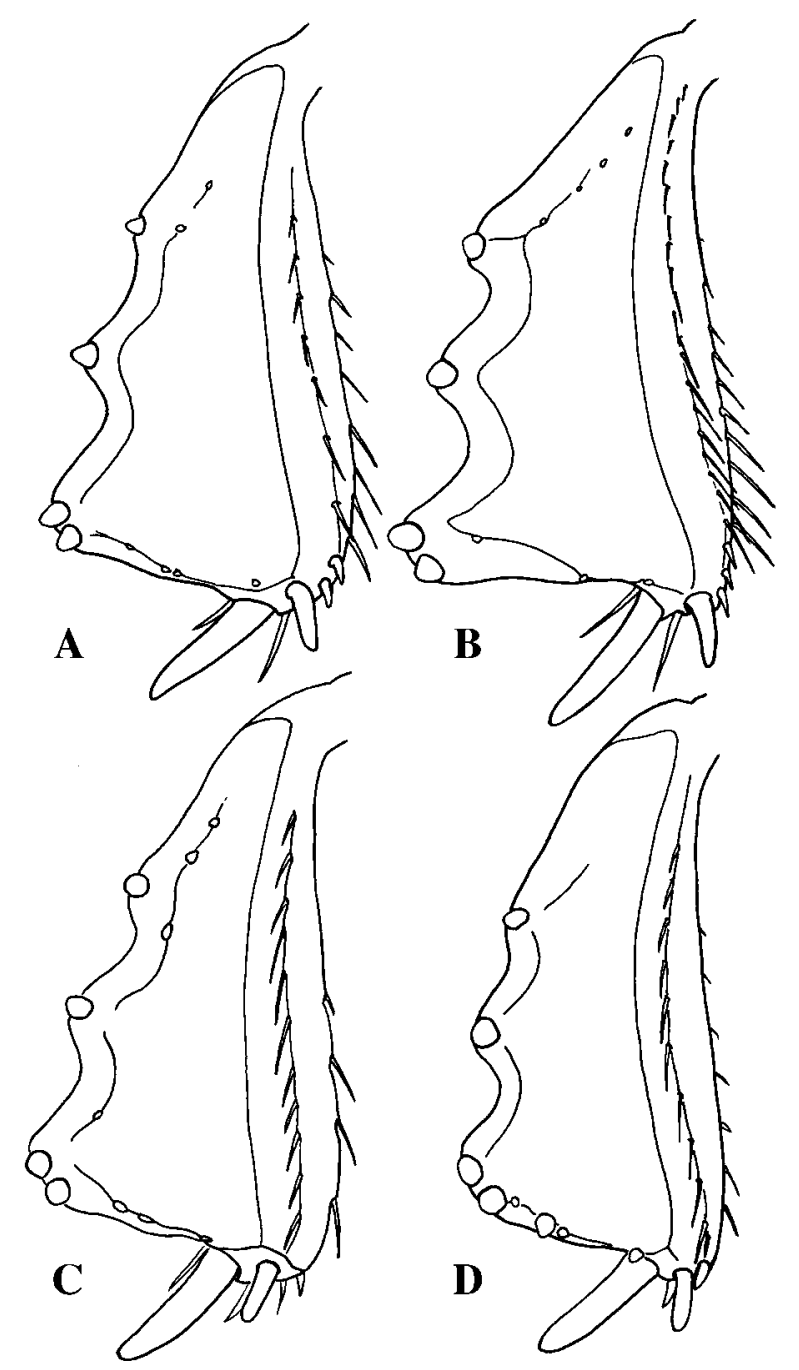

FIGURE 5. Posterior view of protibiae of Hister spp. A. Hister criticus; B. H. latimargo; C. H. guanacaste; D. H. foveipygus. 

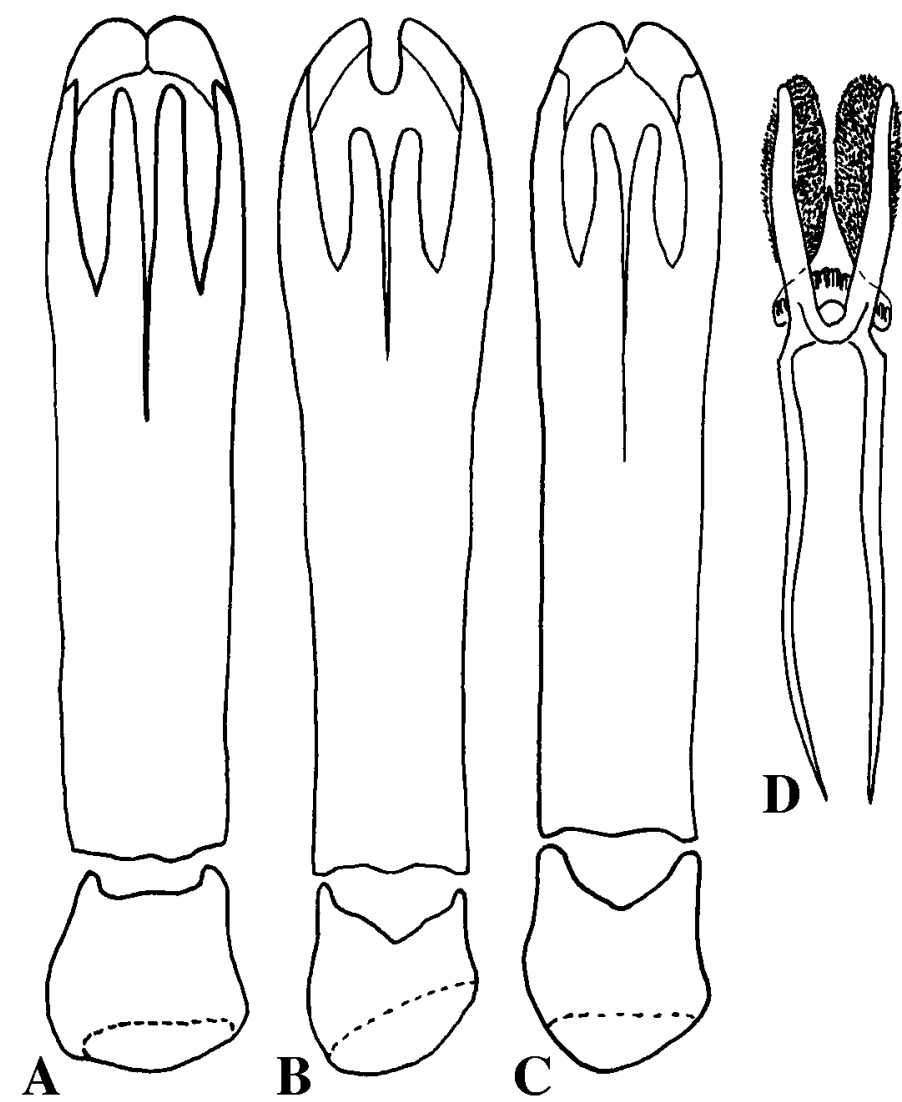

FIGURE 6. Dorsal view of components of aedeagus of Hister spp. A. Tegmen of Hister criticus; B. Tegmen of $H$. guanacaste; C. Tegmen of H. foveipygus; D. Median lobe of H. foveipygus.

Remarks: There is some discrepancy between the published data and those on the the three 'type' specimens of these two species. First, Lewis does not report numbers of specimens for either species. The BMNH presently has two specimens labelled, apparently by Lewis himself, as Hister laevimargo, one collected by Donckier, labelled the 'Type', and one by P. Biolley, from Barba Esmeralda, as the 'Co-type'. Only the latter data is cited in the original description for that species. The one specimen of $H$. planimargo bears a "Costa Rica, (Donckier)" label, as cited. It seems that Lewis confused these specimens in the labelling, and that the specimen of H. laevimargo labelled Co-type (with the correct label data) should be considered the primary type of the species, and it is designated as such. The other two specimens, both collected by Donckier, are considered syntypes of $H$. planimargo, despite the fact that only one bears Lewis' $H$. planimargo label. This latter specimen is designated the lectotype, and the other is not specifically designated.

Describing $H$. planimargo, Lewis notes only that it is related to $H$. laevimargo (and $H$. latimargo), but does not specify characters by which they differ. The most obvious differ- 
ence in their descriptions is how Lewis describes the frontal stria, "sinuous behind the mandibles, angulate above the eyes" in H. laevimargo, and "nearly straight anteriorly" in H. planimargo. However, elsewhere in their descriptions different language is used to describe apparently similar conditions, making it difficult to determine what he considered significant. In any case, in none of these characters can I detect any clear differences.

\section{Hister latimargo Schmidt (Figs. 1, 3C, 4C, 5B)}

Hister latimargo Schmidt, 1893: 14; type locality: "Mexico". The type of H. latimargo is lost. An empty card with Schmidt's type label bearing an appropriate locality label is present in ZMHB, but no loose specimens remotely matching Schmidt's description have been found. The identity of the species, however, is in little question. Several very distinctive characters are adequately described by Schmidt. In particular, the 'fronte biimpressa', 'mandibulis concavis', 'thorace lateribus rotundatim angustato, angulis anticis impressis, stria laterali unica integra, a margine valde distante', 'propygidio densissime punctato, margine subelevato angusto laevi', and 'prosterno angustissimo pone coxas triangulari bistriato'. Furthermore, Lewis, who likely either had specimens identified by Schmidt, or actually saw his type, identified several specimens as this species, now at BMNH.

Diagnosis: This species is among the most easily recognized New World Hister. The single lateral pronotal stria very distant from the margin, with the intervening area strongly convex, is not seen elsewhere in the group. The combination of this with the compressed (nearly triangular in cross section), bistriate prosternum, and the depressed frons provide an unambiguous diagnosis.

Description: Average length: $4.1 \mathrm{~mm}$ (range 3.6-4.7); Avg. width: $4.0 \mathrm{~mm}$ (range 3.64.5); body black and shining, broadly oval, the outline interrupted at the pronotal/elytral junction, both separately outwardly arcuate, with the apex of the mesepimeron prominent between; frons depressed behind carinate frontal stria, most strongly on either side of middle, with conspicuous, though minute punctures; frontal stria bisinuate; supraorbital stria absent; labrum transversely convex, about $1.5 \mathrm{x}$ as wide as long; mandibles flattened above, curving slightly upward at apices, notched at upper basal corners, right incisor with prominent tooth at base, left edentate.

Pronotal sides strongly rounded, widest about one-fourth from base; marginal pronotal stria hidden beneath sides in basal three-fourths, ascending abruptly near apex, thence following anterior margin, ending behind eye; outer lateral pronotal stria absent, inner complete, distant from margin, intervening space convex; inner lateral stria continuous with anterior marginal stria along anterior pronotal emargination; posterior edge of pronotum with irregular marginal punctures, disk otherwise impunctate; hypomeron somewhat excavate; prosternal keel laterally compressed, with two striae parallel, approximate in apical two-thirds (rarely obsolete anteriorly), divergent at base; lateral striae of prosternal keel deeply impressed, recurving inwardly behind presternal suture; prosternal lobe subtriangular, broad, reaching hypomera; incomplete outer, and complete inner, marginal striae 
deeply impressed at their bases; protibia tridenate, the apical tooth bispinose, with complete submarginal carina bearing 2-3 small spinules near its base (Fig. 5B).

Elytron short, wider at maximum width than length along suture; elytral sides arcuate, widest behind middle, their lateral curvature discontinuous from that of pronotum; inner and outer subhumeral striae absent, dorsal striae 1-3 complete, stria 4 slightly abbreviated from base, stria 5 present in apical one-fourth or less, sutural stria present in apical onehalf or less. Mesosternum shallowly emarginate, with complete marginal stria joining postmesocoxal stria at sides; mesepimeron prominent between bases of pronotum and anterior elytral corners; mesometasternal stria broadly interrupted at middle, laterally extending straight back to near metacoxae, abruptly bent forward (often interrupted) at this point, extending to middle of metepisternum; meso- and metasternal disks smooth at middle, shallowly punctate at sides; first abdominal ventrite with two oblique striae along inner edge of each metacoxa; mesotibia weakly arcuate, metatibia nearly straight, both with two rows of marginal spines.

Propygidium and pygidium both with densely alutaceous ground sculpture extending not quite to edges; propygidium shallowly but conspicuously depressed on each side, with evenly spaced medium sized punctures separated by about their widths; pygidium similarly punctate, with punctures not confined to the alutaceous area (Fig. 4C).

Male: aedeagus very similar to that figured for $H$. criticus (Fig. 6A); tegmen only very slightly expanded to apex; probably not diagnostic.

Female: Ovipositor not obviously different from that of $H$. foveipygus, described below (Fig. 8B).

Records (Fig. 1): Hister latimargo is rather widely distributed, from central Mexico into Costa Rica. The species occurs primarily, and probably exclusively, in the refuse deposits of leaf cutting ants. Records: MEXICO: (country label only) (BMNH); San Luis Potosí, 14 mi N. Tamazunchale, 300', refuse deposit Atta mexicana, June (FMNH); San Luis Potosí, El Naranjo (3 mi W), 1100 ft., 22³1'N 99²1'W, June, refuse deposit Atta mexicana (FMNH); Jalisco, Autlán (9.5 mi SW), Puerto Los Mazos, $4400 \mathrm{ft}, 19^{\circ} 42^{\prime} \mathrm{N}$ $104^{\circ} 23^{\prime} \mathrm{W}$, September, refuse deposit Atta mexicana (FMNH); Jalisco, Chapala, San Juan Cosalá, 1500m, ex. Atta mexicana, July (CZUG); Jalisco, Chapala Ajijic, 1475-1600m, July, (CZUG); Jalisco, Tala, Ahuisculco, 1350m, ex. Atta mexicana, November, (CZUG); Jalisco, Tlaquepaque, Parque Montenegro, 1600m, detrito de Atta mexicana, October, (CZUG); Jalisco, 5 mi W Guadalajara, June (UCRC); Colima, Carrizalillo, ex. Atta mexicana, December (CZUG); Hidalgo, Chapulhuacán (8.7 mi SW), $4300 \mathrm{ft}, 21^{\circ} 08^{\prime} \mathrm{N}$ 98 59'W, June, refuse deposit Atta mexicana (FMNH); Veracruz, Fortin, Canyon SW of R. Metlac, 3200-3400', refuse deposit Atta mexicana, July (FMNH); Morelos, Tlayacapan, detrito Atta mexicana, November (CZUG); Distrito Federal, Tejupilco, 3960', July (BMNH); Puebla, Atlisco (BMNH); Oaxaca, 9 mi NE Oaxaca on Mex. 175, 6000 ft., $17^{\circ} 08^{\prime} \mathrm{N} 96^{\circ} 37^{\prime} \mathrm{W}$, refuse deposit Atta mexicana, July, August (FMNH); Oaxaca, Huajuapan de León (6 mi NW), 6400 ft, 1752'N 97²9'W, September, refuse deposit Atta mexi- 

COSTA RICA, Guanacaste, Est. Palo Verde, Ref. Nac. Fauna Silv. R. L. Rodriguez, 10m, June (INBI); EL SALVADOR, San Salvador, June (USNM).

\section{Hister guanacaste n. sp. (Figs. 2, 4D, 5C, 6B, 7A, 8A)}

Types: HOLOTYPE male (dissected by the author): "Est. Palo Verde, $10 \mathrm{~m}$, P. N. Palo Verde, Prov. Guan., COSTA RICA, 4 a 7 may 1992. U. Chavarría. L-N-259000-388400" [INBIO CRI001 213387]; PARATYPES (28): 11: same data as type (INBIO \#'s CRI001 213361, CRI001 213363, CRI001 213368, CRI001 213370, CRI001 213372, CRI001 213398, CRI001 213400, CRI001 213403, CRI001 213404, CRI001 213405, CRI001 213431); 5: "Est. Palo Verde, 10m, Ref. Nac. Fauna Silv. R. L. Rodriguez, Prov. Guan., COSTA RICA, U. Chavarría. Jun 1991. L-N-259000-388400" (CRI000 573317, CRI000 573318, CRI000 581027, CRI000 581031, CRI000 581064); 4: identical data as preceding except collected May 1991(CRI000 346418, CRI000 346473, CRI000 346474, CRI000 510745); 2 identical data as preceding, except collected in Jun 1991 by D. Acevedo (CRI000 449970, CRI000 449978); 3: "3 km NO de Nacaome, 100m, P. N. Barra Honda, Prov. Guan., COSTA RICA. 3 a 30 may 1993. M. Reyes. L-N-239000, 386000" (CRI001 401381, CRI001 402254, CRI001 401926); 3: "Sect. Palo Verde, Prov. Guana, COSTA RICA, 10m, 4-24 ABR 1995. E. Navarro, Interseccion, L N 259150388500 \#4616" (CRI002 184890, CRI002 184891, CRI002 184904).

Diagnosis: This species is closely related, and similar in most respects, to the following (H. foveipygus). Its most distinctive feature is the almost entirely impunctate pygidum and propygidium, the latter with only small punctures along its anterior margin (Fig. 4D). It also has the third elytral stria characteristically interrupted, absent from most of the apical half of the elytron, though invariably with a very short apical appendix. In H. foveipygus (as well as some individuals of $\mathrm{H}$. criticus) this stria is barely or not at all interrupted.

Description: Average length: $4.0 \mathrm{~mm}$ (range 3.8-4.4); Avg. width: $3.8 \mathrm{~mm}$ (range 3.44.2); body black and shining, ovoid, outline not interrupted at the pronotal/elytral junction; frons broad, convex, minutely punctulate; frontal stria bisinuate, strongly impressed, ending at dorsal margin of eye, frons depressed within; supraorbital stria absent; epistoma convex, narrowed anteriorly, emarginate; labrum rounded, convex, about two-thirds as long as wide, anterior margin recessed; mandibles depressed at anterobasal angles, dorsal surfaces flat, incisors lacking teeth; antennal scape about as long as mandible, curved; funicle gradually expanded, to about two-thirds maximum width of antennal club; club ovoid, flattened, with annuli oblique, lacking sensory plaques.

Pronotum with sides rounded, converging; marginal pronotal stria ending behind eye; outer lateral stria absent, inner stria slightly abbreviated at base, continuous with anterior marginal behind head; lateral pronotal margin weakly but noticeably convex; pronotal disk with few small punctures along basal margin, elsewhere no more than minutely punctu- 
late; prosternal keel lacking striae (with basal fragments in few individuals); prosternal lobe rather narrowly rounded anteriorly, with one complete marginal stria, and second abbreviated stria in basolateral half, extended to hypomeron by narrow, sinuate alae. Protibia tridentate, apical tooth bispinose, with complete submarginal carina, bearing a few small spinules, including one or two along apical tibial margin; apical spurs prominent (though often worn) (Fig. 5C).

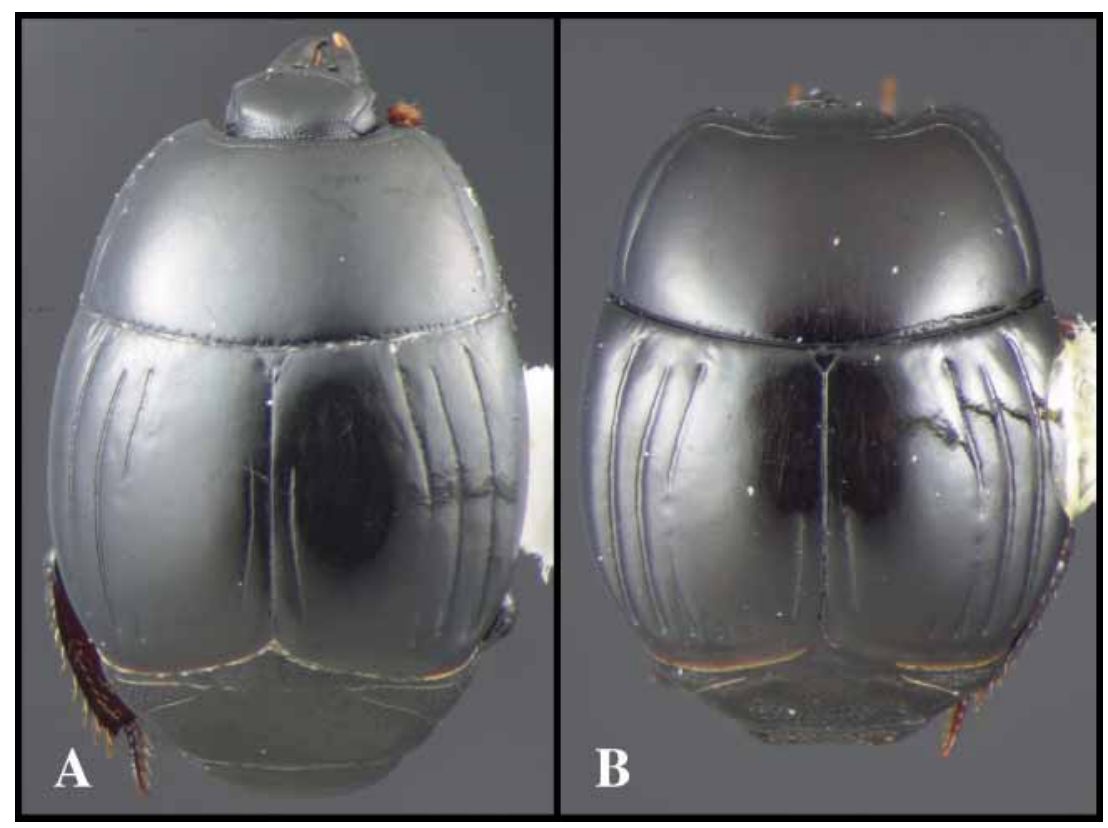

FIGURE 7. Dorsal habitus photographs of Hister spp. A. Hister guanacaste; B. H. foveipygus.

Elytra lacking inner and outer subhumeral striae; striae 1 and 2 complete; stria 3 rarely complete, usually present only in basal one-third and apical one-sixth; striae 4 and 5 absent; sutural stria present in apical one-half or slightly more. Mesosternum shallowly emarginate, with one complete marginal stria, and fragments of an additional stria in anterior corners; metasternal postcoxal stria extending from end of mesosternal stria to mesepimeron; lateral metasternal stria originating near inner edge of mesocoxa, extending obliquely to near metacoxa, then bending at nearly right angle forward to metepisternum. 1 st visible abdominal sternite with one stria extending from anteromedial corner of metacoxa almost straight back to posterior margin of sternite, with a second strial fragment near posteromedial coxal corner. Meso- and metatibiae weakly arcuate, with two series of marginal spines; apicoventral margin of basal tarsomeres of meso- and metatarsi with 2 inner and 1 outer spines, tarsomeres $2-4$ with single pair of marginal spines.

Propygidum and anterior half of pygidium (Fig. 4D) with conspicuous transverse microsculpture; propygidium nearly flat, very shallowly depressed on either side of middle, with small punctures separated by slightly more than their widths along anterior mar- 
gin (slightly finer and sparser at middle), becoming nearly impunctate posteriorly; pygidium strongly convex, evenly inconspicuously punctulate throughout.

Male (Fig. 6B): aedeagus slender, tegmen expanded apically, with unique, deep apicoventral emargination.

Female (Fig. 8A): Ovipositor short, well sclerotized; coxite apically bidentate, twofifths entire ovipositor length; bursa reduced, flattened, weakly sclerotized; 5 linear, slightly apically bulbous spermathecae attached to oviduct near base of bursa, four of them approximately equal in length to bursa, the 5th reduced, about one-third length of others.

Remarks: This species, named for the province of Guanacaste, is only known from lowland areas near the Gulf of Nicoya in northwestern Costa Rica.

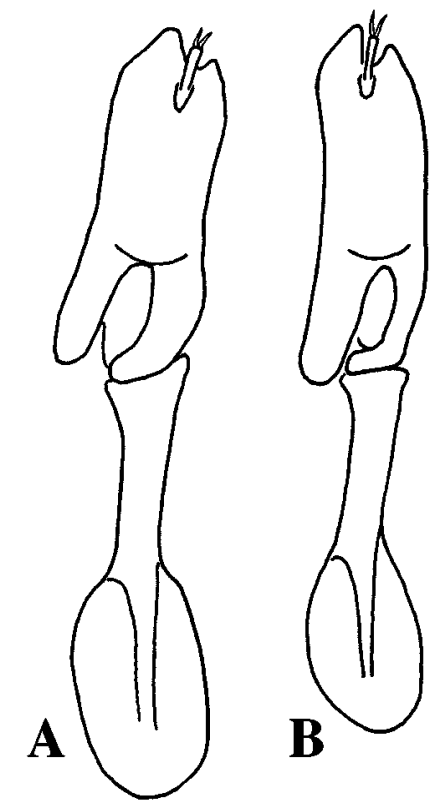

FIGURE 8. Lateral view of valvifer and coxite (ovipositor) of Hister spp. A. Hister guanacaste; B. H. foveipygus.

Hister foveipygus Wenzel \& Dybas (Figs. 2, 4E, 5D, 6C-D, 7B, 8B)

Hister foveipygus Wenzel \& Dybas, 1941: 456; holotype probably male (disarticulated and missing genitalia): "Barro Clrdo Is. PANAMA, C.Z., VII:20:38 - 652"/ "Coll. by E.C. Williams"/ "Collection R. L. Wenzel”, [FMNH]; examined 1997.

Diagnosis: Hister foveipygus is generally similar to the preceding species, and is only described here to the extent that they differ: Average length: $3.3 \mathrm{~mm}$ (range 3.1-3.6); Avg. width: $3.2 \mathrm{~mm}$ (range 3.1-3.4); body smaller, more distinctly flattened, with the outline slightly but distinctly interrupted at the pronotal/elytral junction (Fig. 7B); mandibles 
short, convex (rather than flattened) anteriorly; pronotal margin slightly more conspicuously convex; protibia narrower, with its apical tooth less prominent, its apical margin oblique (Fig. 5D); elytral stria 3 more nearly and frequently complete (though still interrupted behind the middle in many individuals); striae 4 and 5 represented by deeply impressed apical fragments; propygidium with well defined, shallowly depressed, densely punctate area occupying most of its apical two-thirds, though with elevated impunctate margins on either side; pygidium similarly densely punctate in most of basal two-thirds, impunctate apically (Fig. 4E); all ventral tarsal setae fine, characteristically recurved back toward tarsus; male with tegmen of aedeagus smaller and more nearly parallel sided than above, its apical emargination very narrow, acute (Fig. 6C); internal structure of median lobe and associated armature (Fig. 6D) without obvious differences from that of $\mathrm{H}$. guanacaste; female with valvifer of ovipositor relatively shorter than above, equal in length to coxite (Fig. 8B); six spermathecae present, four approximately equal in length to bursa, two about half as long. (Possible variation in number and degree of development of spermathecae has not been investigated. It seems unlikely that this difference from $\mathrm{H}$. guanacaste will be consistent.)

Records (Fig. 2): COSTA RICA (all INBI, except as noted): Limon, Amubri, A. C. Amistad, 20 m, March; Puntarenas, Res. Biol. Carara, Laguna Meandrica, 100m, June; Puntarenas, Res. Biol. Carara, Est. Quebrada Bonita, 50m, May, June, July, August, September; Puntarenas, Parque Nacional Corcovado, Est. Sirena, 100m, May, June, August (INBI, SEMC); Puntarenas, Peninsula de Osa, Rancho Quemado, May, June, July; Puntarenas, Res. Biol. Carara, Est. Quebrada Bonita, 50m, May, June, July, Aug., Sept., Oct.; Puntarenas, Parque Nacional Corcovado, Est. Sirena, 100m, May, June; Puntarenas, Parque Nacional Manuel Antonio, 80m, May; July. PANAMA (all SEMC): Barro Colorado Island, Aug.; Colon, P. N. Soberania, June; Colon, 15 km N. Jct. Escobal \& Pina Rds., 30m, June.

Remarks: The type specimen was collected from 'leaf mold'. Unfortunately no subsequently collected specimens have any ecological data. Most other specimens have been collected using flight interception traps. Aside from the unique type, from Barro Colorado Island, Panama, most available specimens are from Puntarenas Province, Costa Rica. Some differences between the original description and that given above are due to the type being a badly worn individual (e.g., its lack of protibial dentation and 'blunt mandibles'; Wenzel \& Dybas, 1941). Others, however, such as the type's complete lack of 4th and 5th dorsal striae, and its possession of abbreviated prosternal striae, seem to be geographically consistent. More material from the intervening areas is needed to assess the significance of these differences.

\section{Discussion}

Phylogenetic relationships among these species are difficult to assess. Each species exhib- 
its more or less distinctive autapomorphies. But apart from these superficial differences, there is little structural variation among these species. The most generalized appearing species, $H$. criticus and $H$. laevimargo, are also represented by minimal material, and internal reproductive characters, which may prove informative, cannot yet be satisfactorily assessed. The broader phylogenetic position of this group within Hister is similarly unclear. Gross similiarities in body form and aedeagus morphology to members of the Hister servus group may prove more than incidental. However, a higher level analysis of Histerini on a global scale will be necessary before any such ideas can be defended. Freshly collected material of all of these species suitable for molecular work would be highly desireable. Ecological data might also provide valuable phylogenetic information, particularly to the extent to which inquilinous habits are exhibited by others of these rarely collected species. In summary, these are intriguing, but very poorly known components of neotropical beetle diversity.

\section{Acknowledgments}

The efforts of numerous individuals for providing material for this study are sincerely appreciated: R. Anderson, N. Berti, M. Brendell, R. Brett, Z. Falin, F. Genier, D. Kavanaugh, P. Kovarik, J.L. Navarrete-Heredia, A. Newton, A. Solís, A. Tishechkin, M. Uhlig and R. Wenzel. For funding and facilitating a visit to INBio, I thank A. Herrera. This study was also supported by the Schlinger Foundation.

\section{References}

Caterino, M.S. (1998) A phylogenetic revision of Spilodiscus Lewis. The Journal of Natural History, 32(8), $1129-1168$.

Caterino, M.S. (1999a) Taxonomy and phylogenetics of the coenosus group of Hister. University of California Publications in Entomology, 119, 1-93.

Caterino, M.S. (1999b) A taxonomic and phylogenetic revision of the Hister servus species group. Systematic Entomology, 24, 351-376.

Caterino, M.S. (2002) Revision of the Hister militaris group (Histeridae). Annals of the Entomological Society of America, 95(3), 323-334.

Caterino, M.S. \& Arriagada, G. (2003) Un nuevo Hister L. psamophilo de Chile. Revista Chilena de Entomologia, 29, 67-69.

Caterino, M.S. \& Kovarik, P.W. (2001) A new species of Spilodiscus (Coleoptera: Histeridae) and a reevaluation of Spilodiscus phylogeny. Coleopterists Bulletin, 55(2), 134-143.

Lewis, G. (1900) On new species of Histeridae and notices of others. Annals and Magazine of Natural History (7), 5, 246-254.

Marseul, S.A. (1861) Supplement a la monographie des Histerides. Annales de la Societe Entomologique de France (4), 1, 509-566.

Schmidt, J. (1893) Neue Histeriden. Entomologische Nachrichten, 19, 5-16

Wenzel, R.L. \& Dybas, H.S. (1941) New and little known Neotropical Histeridae. Fieldiana (Zoology), 22, 433-472. 